\title{
EDUCATION OF CREATIVE PERSONALITY OF A MUSICIAN BY MEANS OF INTERACTIVE METHODS OF TEACHING
}

\section{ВИХОВАННЯ ТВОРЧОЇ ОСОБИСТОСТІ МУЗИКАНТА ЗА ДОПОМОГОЮ ІНТЕРАКТИВНИХ МЕТОДІВ НАВЧАННЯ}

\author{
Mykhaskova Maryna ${ }^{1}$ \\ Ilinitska Nataliia ${ }^{2}$
}

DOI: https://doi.org/10.30525/978-9934-571-78-7_23

Abstract. The purpose of the article is to reveal the practical possibilities of using interactive methods for teaching materials in the professional training of teachers-instrumentalists at the lessons of professional direction in higher education institutions. The methodology of the research is based on the application of the philosophical idea of the essence of the individual as a creator, subject of culture and culturaleducational activity, harmonious development of the personality, role of art in the education of the personality, dialectical interaction of his or her potential and actual opportunities, scientific-theoretical positions on the unity and interdependence of the general and professional development of a person. The scientific novelty is in the introduction of the proposed methods of interactive teaching at the lessons (practical, laboratory) and in the independent work of students of the specialty «Teacher of Playing Musical Instrument». Interactive methods (business theater, gaming situations, brainstorming, «Microphone», «Unfinished sentences», review and analysis of specific life situations, analysis of dilemmas (problems), «Carousel», simulation or operating games, case-method, method of psychodrama and social drama, «Aquarium», PRESS method, role-playing game, method of authentic assessment of achievements of pupils (portfolio), method of mutual control, method «Teaching through learning», method «Looking for mistakes», work in small groups) will help performers to

\footnotetext{
${ }^{1}$ Candidate of Pedagogical Sciences, Assistant Professor,

Head of the Department of Theory and Methods of Music Art, Khmelnytskyi Humanitarian-Pedagogical Academy, Ukraine

${ }^{2}$ Candidate of Pedagogical Sciences, Assistant Professor,

Khmelnytskyi Humanitarian-Pedagogical Academy, Ukraine

(C) Mykhaskova Maryna, Ilinitska Nataliia
} 
plunge into specific practical problems (situations), find options and ways to solve them. They allow students to ensure the professional orientation of education, in practical teaching to pay more attention to the specifics of the chosen specialty, to form the corresponding skills in practice, to establish the process of interaction between the teacher and the student, to diversify the ways of information exchange, to jointly solve the problems of theory, to simulate the situation of practice, to assess the actions of colleagues and their behavior. The use of interactive teaching methods requires from teachers new creative thinking and constant self-improvement. These methods develop students' creative thinking and lead to creative activity, which is typical for the specificity of music education. It is assumed that the use of materials of the article in the process of teaching students to play piano in higher educational establishments will be effective if the proposed methods are applied systematically and comprehensively to enhance the cognitive activity of students and the development of their musical-creative abilities. They can be used in the development of new programs for the subjects of specialty direction, improving the methods of teaching piano playing.

\section{1. Ветуп}

У наш час зросла потреба використання інноваційних методів у музичній освіті. На жаль, використання цих методів ми частіше зустрічаємо в загальноосвітній та музичній школі. Упровадження їх у професійну музичну освіту відбувається складно. Це пов'язано з тим, що система освіти досить консервативна.

Сучасна мистецька спільнота намагається знайти шляхи осучаснення методів викладання дисциплін фахового спрямування, щоб досягти кращих результатів у підготовці майбутніх викладачів-інструменталістів і вийти за межі академічної замкненості. Одним із таких шляхів ми вбачаємо упровадження методів інтерактивного навчання, які допоможуть виконавцям не тільки бути суб' єктами навчання, а й дадуть можливість навчатися в співпраці з наставниками. У цьому випадку викладачі стають більш досвідченими організаторами процесу отримання знань, умінь і навичок. Вони допомагають студентам розкрити індивідуальність, самобутність у проведенні занять $з$ фаху та у виконанні музичних творів (вокальних, інструментальних, хорових тощо). 


\section{Chapter «Pedagogical sciences»}

Модернізація в системі музичної освіти диктує пошук методів навчання. На підставі робіт В. Іванченко, В. Лазарєва, І. Милославського, М. Поташника під інновацією ми розуміємо створення, розробку і впровадження нововведень, а також їхнє перетворення на вдосконалений продукт, який використовується в практичній діяльності [1]. Питання інноваційної діяльності в галузі освіти розробляють сучасні вчені-педагоги (I. Бех, I. Зязюн, О. Киричук, В. Кремень, В. Кузь, В. Мадзігон, К. Макагон, С. Подмазін, М. Ярмаченко та ін.). Проблемами впровадження в практику і поширення інноваційних педагогічних ідей займалися В. Загвязинський, Л. Подимова, В. Сластьонін; вивченням і узагальненням світового педагогічного досвіду інноваційного спрямування - М. Кларін, Т. Кошманова та інші [2, с. 3].

Одним із різновидів інноваційних технологій є інтерактивні. Методологічну основу інтерактивної технології вивчали В. Гузєєв, О. Пометун, А. Нісімчук, О. Падалка, О. Пєхота та інші. Розкриттям теоретичних основ інтерактивних методів навчання займалися свого часу Ю. Бабанський, М. Поташник. Однак ці дослідження розкривають означені підходи до освітньої діяльності, але не спрямовані на аналіз їхнього застосування в музично-виконавській діяльності в процесі фахової підготовки викладачів-інструменталістів.

Метою нашої статті є розкриття практичних аспектів застосування інтерактивних методів у фаховій підготовці викладача-інструменталіста на заняттях $з$ фахових дисциплін в закладах вищої освіти мистецького спрямування, що сприятиме розширенню всебічного кругозору, удосконаленню слуху, музичної пам'яті, почуття ритму, розвитку креативного мислення, ініціативи і творчої уяви в студентів

\section{2. Виклад основного матеріалу}

Сьогодні доводиться констатувати той факт, що музична підготовка виконавців украй слабка або відсутня повністю. Тому викладачі фахових дисциплін розширюють методи навчання. На межі XX-XXI століть важливе практичне значення набули інноваційні методи навчання. Використання цих методів викладачами, на нашу думку, сприятиме музичному та професійному розвитку студентів закладів вищої освіти.

Виховання в майбутніх викладачів гри на музичному інструменті позитивного ставлення до їхньої виконавської та концертної діяльності, формування загальнопедагогічних навичок та вмінь можливе 
завдяки використанню в навчальному процесі саме інтерактивних технологій навчання на заняттях $з$ дисциплін психолого-педагогічного та виконавського циклу.

Аналізом теорії і практики використання цих технологій займалися О. Пометун та Л. Пироженко. Вони зазначили, що «сутність інтерактивного навчання полягає в тому, що навчальний процес відбувається за умов постійної, активної взаємодії всіх учнів. Це співнавчання, взаємонавчання (колективне, групове навчання у співпраці)...» [7, с. 7].

Перед нами стояло два основні завдання:

- вивчити інтерактивні методи в педагогічній літературі;

- розкрити можливості застосування інтерактивних методів навчання музиці на уроках основного музичного інструменту (фортепіано) та предметах теоретичного циклу.

У нашому дослідженні пропонуємо варіанти використання інтерактивних методів подачі матеріалу в процесі професійної підготовки виконавця-інструменталіста. Так, у фаховій підготовці предмети психолого-педагогічного циклу можуть займати одне з визначних місць. Ці предмети вивчають загальні засади музичної та виконавської педагогіки, теорії навчання й музичного виховання з метою вдосконалення його змісту і методів. Саме на заняттях 3 цього предмета студенти отримують уявлення про різні види музичного навчання в історичній перспективі, про важливі виховні процеси та їхні закономірності, у них виробляються професійні критерії художніх цінностей того чи іншого явища [9].

Проаналізуємо використання методів інтерактивного навчання на аудиторних заняттях з фахових дисциплін (практичних, лабораторних) та в самостійній роботі студентів спеціальності «Музичне мистецтво».

У процесі реалізації методів ситуативного моделювання, зокрема ділового театру, на практичному занятті з «Музичної педагогіки» фахівцю пропонують уявити таку ситуацію:

- на занятті в класі основного музичного інструменту дитина відмовилася слухати та виконувати твори класичного мистецтва, а хоче залучати тільки сучасні обробки творів і розважальну музику. Подумайте: а) як ви будете переконувати учня і як будете доводити свою думку; б) які приклади використаєте в цій ситуації? Виконавець має мобілізувати весь досвід, знання, навички, зуміти вжитися в образ певної особи, зрозуміти іiі дії, оцінити ситуацію і знайти правильну лінію поведінки та аргументувати свою позицію. 


\section{Chapter «Pedagogical sciences»}

На аудиторних (практичних) заняттях методичного спрямування можна використовувати ігрові ситуащії, як-от:

- батьки дитини продовжують займати вас розмовою, а вам потрібно йти на урок з фаху. Ви говорите...;

- ваш учень не задоволений оцінкою за виконання музичного твору. Ви говорите йому...;

- люди, які сидять за вами у філармонії, заважають вам гучною розмовою. Ви звертаєтесь до них...;

- ви зайшли до класу, однак вам не подобається атмосфера між учнями. Ви говорите їм...;

- студент просить вас обрати до свого репертуару музичний твір, який йому подобається, а, на вашу думку, вихованець 3 ним не впорається технічно. Ви говорите йому... [6].

Серед колективно-групових методів ми пропонуємо використовувати метод «Мозковий штурм» та обговорювати питання визначення основних функцій викладача-інструменталіста на сучасному етапі. Засвоєння теми «Методологічна культура викладача-інструменталіста: зміст та специфіка» потребує від фахівця вмінь критично мислити, аналізувати, синтезувати, розмірковувати над отриманою інформацією. Ми пропонуємо такі питання для обговорення, які запропонував О. Ростовський [9]:

- Як Ви ставитесь до думки, що без розуміння й переживання музики неможливе пізнання світу почуттів людини? Поясніть свою позицію.

- Як Ви розумієте вислів «Мистецтво - це час і простір, у якому живе краса людського духу» (В.О. Сухомлинський). Поясніть своє бачення.

- Чи згодні ви з думкою В. Медушевського про те, що інтонаційна суб' єктивність музичного твору є єдиним шляхом проникнення в його внутрішній простір? Поясніть свою позицію.

- Поясніть, яким чином музичні твори, які ви можете виконати, сприятимуть осмисленню особистостями таких тез: «Сила музики в iї красі і правді», «Музика - це мистецтво, породжене життям і нерозривно з ним пов'язане».

На початковому етапі засвоєння музичної літератури (зарубіжної та української) можна використовувати питання:

- Як Ви розумієте таку думку Платона: «Музичне мистецтво завершується любов'ю до прекрасного»? 
- Як Ви розумієте таку думку Аристотеля: «Катарсис - мета мистецтва»?

- Як Ви розумієте роль музичного мистецтва в розвитку духовної культури особистості? Поясніть свою думку.

- На фронтоні Дельфійського храму було висічено вислів : «Пізнай самого себе - і ти пізнаєш богів і Всесвіт». Вважають, що ця думка прийшла до греків зі Сходу. Як Ви розумієте цей вислів? Чи може музика сприяти самопізнанню людини?

- Як Ви розумієте думку Боеція: «Тільки той музикант, хто осягає сутність музики не через вправляння рук, а розумом»? [9].

Вправа «Його найкраща риса» проводиться на лабораторних заняттях з теми «Сучасні вимоги до підготовки викладача гри на музичному інструменті». Хід роботи: м'яч кидають по колу та називають безумовні переваги того, кому кидають м'яч. М'яч повинен бути в кожного учасника групи по колу.

Метод «Мікрофон» використовується для обговорення таких питань: поясність, як ви розумієте вислів: «Сприймання дитини слід розглядати не як елементарний рівень, а як особливу сферу життєдіяльності»; чи згодні ви з думкою про те, що успіх формування музичного сприймання залежить насамперед від вирішення суперечностей між потребами учнів в активній музично-творчій діяльності й можливостями їхньої реалізації в навчальному процесі; між провідною роллю вчителя-інструменталіста і самостійним характером музичної діяльності учнів? Чи можна вважати названі суперечності головними?

Цей метод передбачає передачу один одному уявного «мікрофона» 3 метою висловлювання щодо проблеми, яку обговорюють. Так, на занятті 3 «Історії зарубіжної музики» в процесі вивчення творчості російського композитора П. Чайковського студенти висловлюють думки, відповідаючи на питання: у чому полягає сила його музики, якщо його твори знають люди різних національностей зі всього світу? На уроках 3 «Історії української музики» 3 використанням цього методу з'ясовуємо тезу: «М.В. Лисенко є основоположником української музичної класики. Чи правильне це твердження?».

Метод «Незакінчені речення» може реалізуватися на практикумах як продовження незакінченого речення на зразок «можна зробити такий висновок...», «я зрозумів, що...», «на сьогоднішньому занятті я вдосконалив свої вміння...», «на сьогоднішньому занятті найважливішим відкриттям 


\section{Chapter «Pedagogical sciences»}

було...» та інші. Обговорюючи основні вміння майбутнього вчителя-виконавця, ми пропонуємо використовувати продовження таких речень:

якби я обіймав посаду керівника ансамблю..;

ідеалом викладача-інструменталіста для мене є...;

моя найбільша слабкість полягає в тім...;

люблю виконувати твори, які...;

найбільше в учнях мене дратус...;

коли я виходжу на сцену.... .

Обговорюючи прослухані музичні твори на заняттях 3 «Історії зарубіжної музики», ми використовуємо речення, як-от:

- «Цей твір навчив мене...»;

- «Мені найбільше подобається твір Л. Бетховена ..., тому що ...»;

- «Не джерело - море його ім’я, тому що ...» (І.Бах) та інші.

Суть методу «Розгляд та аналіз конкретних життєвих ситуащій» полягає в тому, що учасникам пропонують 3 опорою на власний досвід роботи описати ситуації, у яких культура виконавця виявляла вплив на музичні враження учнів, їхню музичну діяльність.

Метод «Аналіз дилеми (проблеми)» застосовуємо, коли виконавці в колі обговорюють певну дилему (простішу) чи проблему (складну або поліваріантну), зокрема, музична освіта України - технологія переходу до європейського освітнього ринку; чи потрібно навчатися музичному мистецтву, якщо професія не $\epsilon$ престижною?

На занятті з української музичної літератури ми пропонуємо охопити такі питання за допомогою методу «Аналіз проблеми»: «Розкрийте особливості входження української сучасної музики в європейський музичний простір». На практичному занятті з «Історії зарубіжної музики» на тему «Музичний імпресіонізм» група студентів може взяти на себе роль екскурсоводів у Музеї західного мистецтва й описати представників імпресіонізму в образотворчому мистецтві з обгрунтуванням спільних і відмінних рис у музичному і образотворчому мистецтві. За аналогією можна обговорити теми «Музичний класицизм», «Реалізм у музиці», «Музичний експресіонізм» тощо. До питань обговорення можна додати також аналіз творчості композитора Л. Бетховена, його приналежність до романтичного чи класичного напрямку.

На заняттях з гармонії можна запропонувати студентам працювати над розв' язанням задачі або зробити гармонічний аналіз уривку музичного твору методом «Робота в парах». У процесі роботи кращий сту- 
дент може пояснити слабшому теоретичний матеріал або відповісти на запитання, які виникли. Через деякий час утворюються нові пари, у яких кожний партнер виконує нові функції: «учитель» стає «учнем», а «учень» - «учителем». Завданням «учителя» $є$ ставити запитання до щойно опрацьованого матеріалу, тлумачити незрозумілі поняття, виділяти основну ідею. Ще одним з можливих варіантів роботи в парах може бути робота над гармонічним аналізом уривка, у якій студенти згодом обмінюються роботами і перевіряють один одного.

На музично-теоретичних заняттях можна використовувати цей метод у таких інтерпретаціях: студенти, які сидять поряд, обговорюють: життєвий та творчий шлях композитора, вивчений і прослуханий музичний твір, отриману інформацію, підбивають підсумок заняття тощо, беруть інтерв'ю один в одного (стосовно прослуханого твору), анкетують партнера за вивченим матеріалом на занятті (за заздалегідь заготовленими анкетами).

Метод «Карусель». На занятті студенти розподіляються на дві групи і сідають один навпроти одного, утворюючи «карусель». За сигналами викладача вони пересуваються на одне місце, виконуючи такі завдання: розповідають один одному, що було цікавого на занятті; ставлять заплановані запитання, а студенти навпроти них відповідають. Учасники готують по 10 питань із певної теми (наприклад, «Прохідні та допоміжні кватрсекстакорди», «Життєвий та творчий шлях композитора Ф. Шопена», «Характерні риси камерно-вокальної музики в Україні у XX столітті», «Особливості проведення уроків музичного мистецтва в загальноосвітній школі» тощо).

Використовуючи цей метод (тема «Психолого-педагогічні основи формування музичного сприймання дітей»), фахівці можуть запропонувати один одному такі питання:

- назвіть функції, які виконує музичне сприймання;

- що розуміють під структурою музичного сприймання;

- вкажіть елементи структури музичного сприймання;

- розкрийте зміст понять «музичний образ», «музичний зміст», «структура музичного твору»;

- охарактеризуйте сутність процесу музичного сприймання як взаємодії музичного твору і слухача;

- назвіть уміння і навички, потрібні для розвитку музичного сприймання особистості; 
- яка роль комунікативного, мовного і рухового досвіду особи в розвитку музичного сприймання;

- назвіть вікові особливості музичного сприймання;

- назвіть суперечності процесу формування музичного сприймання;

- охарактеризуйте суперечності між виконавцем і слухачем, які виникають у процесі керування музичним сприйманням;

- назвіть логіку керування музичним сприйманням дітей.

Одним із видів самостійних завдань із застосуванням методу імітаційних або операційних ігор може бути написання рецензії на концертну програму (сольний виступ виконавця спеціальності «Музичне мистецтво»)[6] у ролі рецензента або кореспондента. У процесі роботи виконавець відвідує концерт, з'ясовує його програму, мету й концепцію аналізованого заходу. Визначає технічний рівень, відповідність творів вимогам навчальної програми (чи обгрунтованими є відхилення від програми, якщо вони є). 3'ясовує наявність (відсутність) виконавської інтерпретації, визначає міру технічного забезпечення, рівень виконавської витримки. Зазначає бажані доповнення (скорочення) щодо складності виконуваних творів. Складає оцінку якості та технічності виконання. Аналізує можливі зміни (доповнення) щодо змісту концерту. Визначає, наскільки оригінальною є запропонована програма. Формулює висновки (рекомендувати до прослуховування; рекомендувати до виконання за умови виправлення вказаних недоліків; не рекомендувати програми для концертного виступу).

У процесі реалізації кейс-методу майбутнім викладачам-інструменталістам пропонуємо самостійно підготувати роботу на тему «Моральний кодекс викладача гри на музичному інструменті». Також передбачені завдання:

- скласти оріснтовну програму концертного виступу (академічного, звітного, до ювілейної дати); продумати послідовність концертних номерів, визначити загальну режисуру концерту;

- підібрати в методичній літературі та періодиці приклади, які розкривають значення культури педагога у формуванні особистості учня засобами музичного мистецтва.

Залучаючи методи психодрами $і$ соиіодрами, рекомендуємо використовувати техніки: «діалог», «монолог», «виконання ролі», «дублювання», «репліка вбік», «обмін ролями», «порожній стілець», «дзеркало» та інші. Наприклад, можна опрацювати такі ситуації: «вхід до 
класу основного музичного інструменту», «вихід на сцену», «виконання ролі музичного лектора», «який я є за інструментом?», «яким мене бачать інші?», «яким би я хотів бути?», «що для мене найголовніше в професії?», «втіха ображеного учня», «вибір членів інструментальної групи», «перебування на сцені в ансамблі», «ким із героїв музичної казки ти би міг бути?», «почуття, із яким я прийшов у інструментальну групу», «моє ставлення до участі в музичному колективі», «що робила б група, якби не було ведучого на концерті?»

На лабораторному занятті студентам пропонуємо знайти вихід 3 такої ситуації за допомогою методу рольової гри: «На засіданні методичної ради музичної школи один із запрошених гостей (депутат місцевої об'єднаної територіальної громади) заявив, що діти можуть обійтися без музичної школи, тому не обов'язково виділяти приміщення (кошти на придбання музичних інструментів, аудіотехніки тощо). Продумайте:

а) як ви будете переконувати гостя і як будете доводити свою думку;

б) які приклади використаєте в цій ситуації».

До технологій опрацювання дискусійних питань належить метод «Займи позицію». Цим методом варто розпочинати роботу над дискусійними питаннями та проблемами. Його можна використовувати для демонстрації різних поглядів на проблему. Слід використовувати дві протилежні думки, що не мають однієї відповіді [10].

Наприклад, тема «Л. Бетховен. Характеристика творчої спадщини композитора» може містити обговорення твердження «Л. Бетховен композитор-класик чи представник раннього романтизму».

Діяльність викладача щодо реалізації методу «Займи позицію» здійснюється за такою послідовністю:

- на дошці чи біля окремих столів прикріпляються плакати «Так», «Ні», «Не знаю»;

- викладач називає тему та пропонує студентам висловити почергово свою думку з досліджуваної теми;

- після цього студентам пропонується стати біля того плаката («так», «ні», «не знаю»), який відповідає їхній позиції;

- далі студентам пропонує підготуватися до обгрунтування своєї позиції, самостійно або в групі однодумців дібрати декілька найбільш сильних аргументів, які можуть переконати інших у власній правоті, висловити аргументи аудиторії; 


\section{Chapter «Pedagogical sciences»}

- у цей час іншим учасникам рекомендує уважно вислухати аргументи та пропозиції однокурсників.

Якщо після обговорення дискусійного питання студенти змінюють точку зору, то вони переходять до іншого плаката і пояснюють причину своїх дій, а також називають найбільш переконливу ідею чи аргумент протилежної сторони, спираючись на думки студентів [10].

Наступний метод (метод ПРЕС) використовується в процесі вироблення у студентів умінь формулювати аргументи, висловлювати думки 3 дискусійного питання у виразній і стислій формі, переконувати інших [10]. Наприклад, на занятті студентам роздають картки, у яких запропоновано 4 такти музичного твору і декілька трактовок виконання. Викладач дає можливість кожному із учасників висловити свою думку, пояснити, у чому полягає їхня точка зору (починаючи зі слів... я вважаю, щзо...), пояснити причину появи цієї думки, тобто на чому грунтуються докази (починайте зі слів ...mому, щзо..) і навести приклади, додаткові аргументи на підтримку своєї позиції, назвати факти, які демонструють переконливі докази (... наприклад...). У результаті викладач узагальнює і робить висновок, починаючи словами: отже,... таким чином....запропонований варіант студента..... більш переконливим.

За допомогою методу «Акваріум» обговорюють питання: моє професійне покликання; як стати професіоналом; чому потрібно обрати професію викладача гри на музичному інструменті. Студенти в процесі обговорення аргументують свою позицію та доводять думку за допомогою прикладів. Можна також використовувати узагальнені запитання, як-от:

- «Чи погоджуєтесь Ви з думкою групи, яка висловилась?»;

- «Чи була ця думка достатньо аргументованою?»;

- «Який з аргументів Ви вважаєте найбільш переконливим?» тощо.

Метод проектів передбачає розвиток пізнавальних, творчих навичок студентів, умінь самостійно конструювати знання, орієнтуватися в інформаційному просторі, критично мислити [5]. Ці матеріали створюються викладачами та студентами з використанням комп'ютерних технологій (засобів створення мультимедійних комп'ютерних презентацій, текстового та графічного процесорів, табличного процесора, комп'ютерних програм для створення публікацій і веб-сайтів, здійснення пошуку інформації в Інтернеті, роботи з електронною поштою тощо). Наприклад, самостійними роботами з предмета «Історія української музики» можуть бути: 


\section{Mykhaskova Maryna, Ilinitska Nataliia}

- розробка комп'ютерних презентацій про життєвий та творчий шлях композиторів від часів Київської Русі до ХX ст.;

- складання тезового плану-конспекту про життєвий та творчий шлях композиторів від часів Київської Русі до ХХ ст.;

- комп'ютерне моделювання музичних вікторин з тем програмного курсу, тематичне планування, поурочне планування уроків різних типів;

- складання кросвордів з тем програмного курсу;

- розробка проекту «Улюблені пісні українських композиторів» або «Улюблені українські пісні».

Наведемо приклад виконання проектів з предмета «Історія зарубіжної музики»: «Мій улюблений В. Моцарт» (Ф. Шопен, Л. Бетховен тощо); «Мої улюблені фортепіанні твори»; «Наші улюблені пісні» (Ф. Шуберта, О. Даргомижського, німецьких композиторів 19 ст. тощо). Як позаурочний навчальний (музичний лекторій) та виховний захід (концерт тощо) з використанням творчості композиторів студентам пропонуємо розробити план-сценарій. Результати проектних робіт оформлюють у вигляді афіш, запрошень на тематичний концерт тощо.

У методi «Робота в малих групах» найсуттєвішим є розподіл ролей: «спікер» - керівник групи (стежить за регламентом під час обговорення, зачитує завдання, визначає доповідача, заохочує групу до роботи), «секретар» (веде записи результатів роботи, допомагає при підбитті підсумків та їхньому виголошенні), «посередник» (стежить за часом, заохочує групу до роботи), «доповідач» (чітко висловлює думку групи, доповідає про результати роботи групи) [4]. Можливим $\epsilon$ створення експертної групи з сильніших студентів. Вони працюють самостійно, а при оголошенні результатів рецензують та доповнюють інформацію.

Застосовуючи цей метод на музично-теоретичних заняттях, студенти можуть самостійно театралізувати пісню, скласти композицію танцю, ритмічних вправ, озвучити музичну казку, розповідь для школярів за мотивами відомих опер, балетів. Також корисним є створення музично-методичних композицій узагальнювального характеру за стильовими ознаками, як-от: «Музика старовинних італійських майстрів», «Віденська класична школа», «Романтизм у музиці і поезії», «Музика сучасних напрямків», «Перлини класичної музики», «Пам’яті Петра Сокальського присвячуємо», «Ліричні сторінки творчості Левка 


\section{Chapter «Pedagogical sciences»}

Ревуцького», «Народні витоки натхнення Е. Гріга», «Дитячий альбом В. Кирейка», «Музика Ф. Шопена в моєму житті», «Колискові», «Я пам'ятаю звуки вальса», «Баркарола - пісня на воді», «Танцювальна музика народів світу», «Жанр прелюдії: від Баха до Шостаковича», «Виражальність і зображальність у музиці», «Мажор і мінор», «Героїка в музиці», «Ліричні сторінки музичної творчості», «Світ дитячих захоплень», «Музичні іграшки», «Улюблені образи з мультфільмів», «Добрі і злі казкові герої», «Музичний зоопарк», «Ляльки в дитячому куточку», «Музика і цирк» тощо.

Метод автентичного очінювання досягнень учнів (портфоліо) - це тека, у якій у систематизованому вигляді виконавець накопичує матеріали, які є результатом його професійної діяльності. Портфоліо складається 3: дипломів, сертифікатів, грамот за участь в фестивалях, науково-практичних конференціях і семінарах; конспекти додаткових джерел інформації; реферати, тези доповідей на семінарах, есе, творчі роботи; ксерокопії нормативних документів, які стосуються професійної діяльності; результати індивідуальної роботи з викладачем, науковим керівником: плани, програми, проекти наукової статті; анкети, результати опитування, інтерв'ю 3 професіоналами-практиками за фахом студента [8]. Прикладом студентського портфоліо може бути проект на тему «Створи свою візитівку», «3 яким музичним твором я асоціюю себе?», «Моє портфоліо».

Окремо детальніше розглянемо інтерактивні методи, які ми пропонуємо для використання під час вивчення предмету «Основний музичний інструмент (фортепіано)»:

- проектний метод використовується двічі. Перший варіант - підготовка презентації музичного твору на факультетському фортепіанному конкурсі I-II курсів на найкраще виконання п'єс для слухання музики в школі і дошкільному навчальному закладі (тут досягаються дві цілі: перша - освоєння проектного методу, друга - метод взаємоконтролю, коли виступають з презентацією, оцінюють і журі викладачів, і студенти один одного, які вибирають претендента на «Приз глядацьких симпатій»). Другий варіант - підготовка проекту «Музичні колекції» для V-VI курсів, коли три музичні твори колекції об'єднано спільною тематикою (наприклад, «Багатогранність творчості Мирослава Скорика: «Блюз», «Народний танець», «Мелодія»). Студенти не тільки аналізують твори, а й описують виконавські труднощі; 
- метод взаємоконтролю застосовується під час проведення в піаністів відкритих академконцертів (на III i V курсах), де оцінюється гра студентів не тільки викладачами, а й студентами;

- метод «Вчення через навчання» активно використовують магістри під час асистентської практики;

- метод «Шукаємо помилки» часто використовується на першому курсі, коли слабо підготовленому студенту доводиться активізувати зорову увагу і слуховий контроль при роботі над текстом музичного твору на заняттях «Основного музичного інструменту (фортепіано)»;

- креативний метод спрямований на розвиток організаторських та музично-творчих здібностей для створення креативного продукту студентами (наші студенти створили групу BIA «FM» склали і виконали пісню «Ми факультет мистецтв»);

- метод «портфоліо» - основне завдання цього методу допомогти кращим студентам, які беруть участь і займають призові місця на різних фортепіанних конкурсах, скласти портфоліо, у якому будуть оформлені їхні досягнення. Це може допомогти студенту презентувати себе при майбутньому працевлаштуванні.

Для вдосконалення поліфонічних навичок у студентів ми пропонуємо використовувати метод «Вчення через навчання» - уміння слухачів магістратури під час асистентської практики передавати знання студентам молодших курсів. Цей метод проводиться як робота у двійках: магістр грає два крайніх голосу (без середнього) в триголосній поліфонії, а студент грає середній голос на октаву вище (або нижче); другий варіант - гра нижнього голосу двома руками в октаву (в ансамблі зі слухачем магістратури, який грає верхній голос).

- робота в трійках. Особливість цього методу в тому, що робота відбувається без інструменту (викладач може брати участь разом зі своїми студентами). Спочатку троє учасників сідають в один ряд. Той, хто по центру, повинен мовчати, крайні учасники розповідають одночасно різний текст (вірші, казку, прозу тощо). Завдання полягає в тому, що центральний студент повинен постаратися почути те, про що говорили його сусіди.

Другий варіант роботи в трійках. Учасники сідають трикутником і тепер розмовляють всі одночасно. Завдання для всіх одне - почути кожного. Результати роботи в двійках і в трійках з'являються не відразу, цю навичку потрібно напрацьовувати. Така робота поступово навчає студентів чути кілька голосів одночасно, що є однією з основних задач поліфонії. 


\section{Chapter «Pedagogical sciences»}

При підготовці студентів-музикантів предмет «Акомпанемент» (фортепіано) займає одне з провідних місць. Цей курс допомагає підготувати фахівців, які знають і розуміють зміст музичних творів.

Традиційні методи роботи зі студентами на заняттях 3 «Акомпанементу», ми пропонуємо доповнити інтерактивними:

- метод мікрофона використовується на занятті з двома студентами, коли вони використовують різні види акомпанементу для підбору супроводу мелодії пісні по черзі (бажано без зупинок);

- метод незакінченого речення успішно використовується викладачем при навчанні підбору супроводу. Викладач у першій фразі пісні показує, який вид супроводу можна використовувати, а студент повинен підхопити і закінчити куплет;

- кейс-метод допомагає студентам поєднати теоретичні знання 3 практичними, перетворити абстрактні знання студента в уміння щодо цього предмета. Студент отримує кейс і список рекомендованої музичної літератури, самостійно готує пісню до заняття [3].

\section{3. Висновки}

Таким чином, інтерактивні методи допоможуть виконавцям-педагогам зануритися в конкретні практичні проблеми (ситуації), знайти можливі варіанти та шляхи їхнього вирішення. Вони дозволяють фахівцям:

1) забезпечити професійну спрямованість освіти;

2) у практичному викладанні більше враховувати специфіку обраної спеціальності;

3) формувати відповідні навички на практиці;

4) налагодити процес взаємодії викладача і студента;

5) урізноманітнити шляхи обміну інформацією;

6) спільно вирішувати проблеми теорії, моделювати ситуації практики, оцінювати дії колег і свою поведінку.

Метою застосування цих методів є розширення, поглиблення й деталізація наукових знань, отриманих на лекціях та в процесі самостійної роботи, прищеплення умінь і навичок, розвиток наукового мислення та усного мовлення виконавців.

Передбачається, що використання матеріалів роботи в процесі навчання студентів грі на фортепіано у закладах вищої освіти буде ефективним, якщо пропоновані інтерактивні методи будуть застосову- 
ватися систематично і комплексно для посилення пізнавальної активності студентів та розвитку їхніх музично-творчих здібностей.

Таким чином, застосування сучасних методів навчання вимагає у викладачів нового творчого мислення і постійного самовдосконалення. Вони розвивають у студентів креативне мислення і спонукають до творчої діяльності, що характерно для специфіки музичної освіти. Вони є ефективним не тільки для студентів-піаністів, а й для студентів-інструменталістів, які опановують народні інструменти (баян, акордеон).

Перспективою подальших досліджень ми вбачаємо аналіз практичного застосування інтерактивних методів у практичній підготовці на заняттях $з$ диригентсько-хорових дисциплін та вокалу.

\section{Список літератури:}

1. Балуева 3.В. Инновационные методы обучения музыке в учреждении дополнительного образования (на примере детской музыкальной школы) Мордовский государственный педагогический институт имени М. Е. Евсевьева, Саранск, Россия. URL: https://files.scienceforum.ru/pdf/2013/6926.pdf (дата обращения: 30.11.2018).

2. Завалко К.В. Формування готовності майбутнього вчителя музики до інноваційної діяльності: автореф дис. д-ра пед. наук: 13.00.02. Київ, 2013. 41 с.

3. Ilinitska N. Subject "Accompaniment" (fortepiano) - component of professional education of students-pianists in pedagogical educational institutions Sciences of Europe VOL 4, No 35 (2019) (Praha, Czech Republic), pp. 31-35.

4. Інтерактивні методи навчання: теорія і практика впровадження. URL: http://shkola.ostriv.in.ua/publication/code-103F1AF92B958 (дата звернення: 24.02.2019).

5. Метод проектів як технологія. URL: http://pidruchniki.com/11570718/ informatika/metod_proektiv_tehnologiya_navchannya (дата звернення: 24.02.2019).

6. Михаськова М.А. Застосування інтерактивних методів ситуативного моделювання в професійній підготовці майбутніх учителів музичного мистецтва. Актуальні питання мистеиької педагогіки: зб. наук. праць / гол. ред. I.М. Шоробура. Хмельницький: ФОП Стрихар А.М., 2018. Вип. 7. С. 54-57.

7. Пометун О., Пироженко Л. Інтерактивні технології навчання: теорія і практика. К.: А.П.Н., 2002. 136 с.

8. Портфоліо вчителя. Види та структура. URL: http:/helpinformatik.com/ ?id=1193 (дата звернення: 21.02.2019).

9. Ростовський О.Я. Музична педагогіка: навчальні програми, методичні рекомендації та матеріали. Ніжин: Вид-во НДУ ім. М. Гоголя, 2001. 112 с.

10. Технології опрацювання дискусійних питань. URL: https://studfiles.net/ preview/5456785/page:4/ (дата звернення: 21.02.2019). 


\section{References:}

1. Balueva Z.V. Innovatsionnyie metodyi obucheniya muzyike v uchrezhdenii dopolnitelnogo obrazovaniya (na primere detskoy muzyikalnoy shkolyi) Mordovskiy gosudarstvennyiy pedagogicheskiy institut imeni M. E. Evseveva, Saransk, Rossiya. URL: //files.scienceforum.ru/pdf/2013/6926.pdf (last accessed 30.11.2018).

2. Zavalko K.V. (2013). Formuvannja hotovnosti majbutn'oho včytelja muzyky do innovatsijnoji dijal'nosti: avtoref dys. d-ra ped. nauk: 13.00.02. Kyjiv, p. 41.

3. Ilinitska N. Subject "Accompaniment" (fortepiano) - component of professional education of students-pianists in pedagogical educational institutions. Sciences of Europe. vol 4, No 35 (2019), Praha, Czech Republic, pp. 31-35.

4. Interaktyvni metody navchannja: teorija i praktyka vprovadzhennja. URL: http://shkola.ostriv.in.ua/publication/code-103F1AF92B958 (last accessed 24.02.2019).

5. Metod proektiv jak tekhnologhija. URL: http://pidruchniki.com/11570718/ informatika/metod_proektiv_tehnologiya_navchannya (last accessed 24.02.2019).

6. Mykhasjkova M.A. (2018). Zastosuvannja interaktyvnykh metodiv sytuatyvnogho modeljuvannja $\mathrm{v}$ profesijnij pidghotovci majbutnikh uchyteliv muzychnogho mystectva. I.M. Shorobura (Red.). Aktualjni pytannja mystecjkoji pedaghoghiky: zb. nauk. pracj. Vol. 7. pp. 54-57. Khmeljnycjkyj: FOP Strykhar A.M. (in Ukrainian)

7. Pometun O., Pyrozhenko L. (2002). Interaktyvni tekhnologhiji navchannja: teorija i praktyka. K.: A.P.N. (in Ukrainian)

8. Portfolio vchytelja. Vydy ta struktura. Retrieved from http:/helpinformatik.com/ ?id=1193 (last accessed 21.02.2019).

9. Rostovsjkyj O.Ja. (2001). Muzychna pedaghoghika: navchaljni proghramy, metodychni rekomendaciji ta materialy. Nizhyn: NDPU. ([in Ukrainian)

10. Tekhnologhiji opracjuvannja dyskusijnykh pytanj. URL: https://studfiles.net/ preview/5456785/page:4/ (last accessed 21.02.2019). 